\title{
Synthesis and Characterization of New Heterocyclic Schiff's Bases from Methyl 4-Hydroxybenzoate
}

\author{
Saja S. Abbood, Jawad K. Shneine and Ahmed Ahmed \\ Department of Chemistry, College of Science, Al-Nahrain University, Baghdad-Iraq. \\ E-mail: jkshneine@gmail.com.
}

\begin{abstract}
New Schiff's bases with 1,2,4-triazole ring (3a-j) have been synthesized from 4-(4'-amino-5mercapto-4H-1, 2, 4-triazol-3-yl) phenol (2) which is obtained from 4-hydroxybenzohydrazide (1) by a cyclization reaction. Infrared spectroscopy and ${ }^{1} \mathrm{H}$ NMR spectroscopy were used to characterize the structure of synthesized compounds. All the final products are indicated as ketoenol and thione-thiol tautomers.
\end{abstract}

Keywords: Heterocyclic compounds, Schiff's bases, Triazole, tautomerism.

\section{Introduction}

In recent years, 1, 2, 4-triazoles acquire an impressive importance due to their wide range applications such as anticorrosion [1], antioxidant [2, 3 and 4], acid-base indicator [5], urease inhibitors [4, 6], lipase inhibitors [6]. Also they found to be used as anticancer agents [7-8], antibacterial [4], antitubercular [9], and anticonvulsants [10, 11], antiviral [12], anti-inflammatory [13-14].

In literature there are several methods to synthesize 1, 2, 4-Triazole compounds, i.e, the synthesis from 1, 3, 5-Triazine, Oxazole, Thiosemicarbazide, Urea, and from Acid Chloride Carboxylic Acid Hydrazide [15]. The latter method was applied in this work.

Like Triazoles Schiff's bases exhibit a broad spectrum of applications as corrosion inhibitors, insecticides and pesticides. Their complexes with transition metals also have antibacterial, antiviral and antitumor activities.

Many researchers investigate the 1,2,4 Triazole compounds as corrosion inhibitors and found an increased inhibition effect on the corrosion of mild steel in acidic solutions [16].

In this work, the synthesis of Schiff's base derivatives with triazole moiety has to be accomplished and in next future as corrosion inhibitors will be studied.

\section{General}

All starting materials and solvents were purchased from Fluka, BDH and Thomas Baker companies, used without further purification. Melting points were determined on electro thermal capillary apparatus
(Chachan, MLP-01) and are uncorrected. FT-IR measurements were recorded on Shimadzu model FTIR-8400S. ${ }^{1} \mathrm{H}$ NMR spectra were achieved on NMR Spectrometer $400 \mathrm{MHz}$, Avance III 400, Bruker.

\section{Chemical Synthesis}

Synthesis of 4-hydroxybenzohydrazide (1) [18]

4-hydroxy methyl benzoate $(0.01 \mathrm{~mol}$, $1.52 \mathrm{~g})$ in $(25 \mathrm{ml})$ ethanol is taken in a round bottom flask. Hydrazine hydrate $(0.015 \mathrm{~mol}$, $0.73 \mathrm{ml}$ ) was added, and the resulting mixture was refluxed for 4 hours. The precipitate was filtered, washed with ethanol, dried and recrystallized from ethanol.

Synthesis of potassium 2-(4-hydroxybenzoyl) hydrazinecarbodithioate [18]

A mixture of 4-hydroxybenzohydrazide (0.01 mol, $1.52 \mathrm{~g})$, potassium hydroxide $(0.015 \mathrm{~mol}, 0.84 \mathrm{~g})$, and $(0.025 \mathrm{~mol}, 1.9 \mathrm{ml})$ carbon disulfide in $(15 \mathrm{ml})$ of absolute ethanol was stirred for 16 hours. The potassium salt thus obtained was used in the next step without further purification.

Synthesis of 4-(4-amino-5-mercapto-4H-1, 2, 4-triazol-3-yl) phenol (2) [19]

A suspension of potassium salt dithiocarbazinate $(0.01 \mathrm{~mol}, 2.6 \mathrm{~g})$, hydrazine hydrate $(0.02 \mathrm{~mol}, 0.97 \mathrm{ml})$ and water $(40 \mathrm{ml})$ was refluxed for 8 hours. The color of the reaction mixture changed to green, hydrogen sulphide was liberated and a homogenous solution resulted. A white solid was precipitated by dilution with cold water 
(50 $\mathrm{ml})$ and acidification with concentrated hydrochloric acid. The product was filtered, washed with cold water and recrystallized from ethanol.

General procedure for the synthesis 4-(4(benzylideneamino)-5-mercapto-4H-1, 2, 4triazol-3-yl) phenol (3a- 3j) [20]

A mixture of compound $2(0.01 \mathrm{~mol}, 2.1 \mathrm{~g})$ and various aromatic aldehydes $(0.02 \mathrm{~mol})$ in $(50 \mathrm{ml})$ absolute ethanol and two drops of glacial acetic acid, then refluxed for about 10 hours. Precipitate was filtered, dried and recrystallized from ethanol.

\section{Results and Discussion}

Compounds (1), (2), and 3(a-j) were synthesized as shown in Scheme (1). Chemical formula, molecular weight, color, melting points, and yield of prepared compounds are listed in Table (1). FT-IR spectral data are also shown in Table (2).

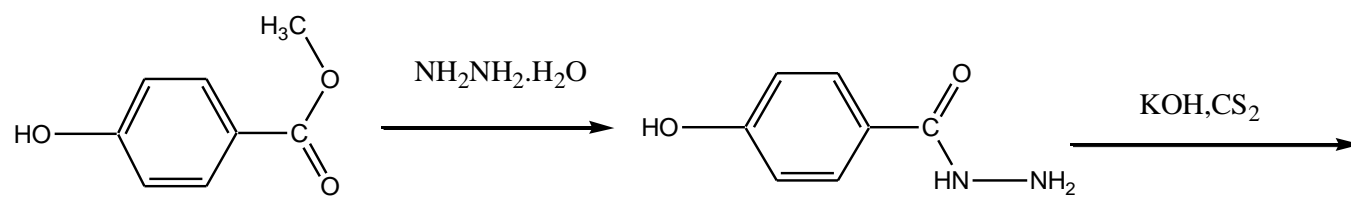

methyl 4-hydroxybenzoate 4-hydroxybenzohydrazide

1

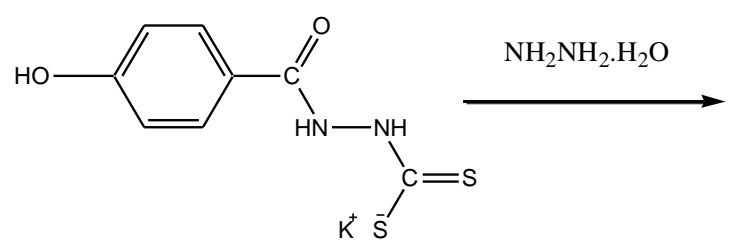

potassium 2-(4-hydroxybenzoyl)hydrazinecarbodithioate

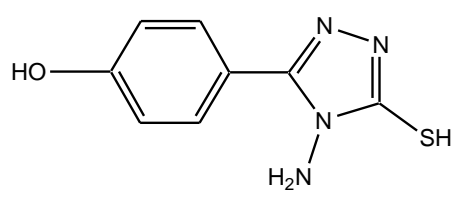

4-(4-amino-5-mercapto-4H-1,2,4-triazol-3-yl)phenol
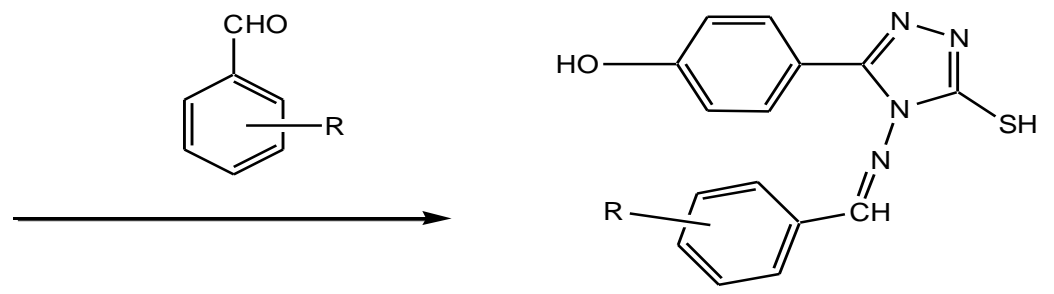

4-(4-(benzylideneamino)-5-mercapto-4H-1,2,4-triazol-3-yl)phenol

$3 \mathrm{a}-\mathrm{j}$

Scheme (1): Synthetic pathway for compounds [1-3(a-j)], where $\left(\mathrm{R}=\mathrm{H}, \mathrm{p}-\mathrm{OH}, \mathrm{p}-\left(\mathrm{CH}_{3}\right)_{2} \mathrm{~N}, \mathrm{p}-\mathrm{Br}\right.$, $\left.o-\mathrm{NH}_{2},\right), \mathrm{p}-\mathrm{CH}_{3}, \mathrm{p}-\mathrm{NO}_{2}, \mathrm{p}-\mathrm{OCH}_{3}, \mathrm{p}-\mathrm{Cl}, \mathrm{o}-\mathrm{OH}$ respectively. 
Table (1)

Physical Properties for Compounds 1- $3(a-j)$.

\begin{tabular}{|c|c|c|c|c|c|c|}
\hline No. & Compound name & $\begin{array}{l}\text { Chemical } \\
\text { Formula } \\
\end{array}$ & \begin{tabular}{|c||}
$\begin{array}{c}\text { Molecular Weight } \\
(\mathrm{g} / \mathrm{Mol})\end{array}$ \\
\end{tabular} & Color & \begin{tabular}{|c|}
$\begin{array}{c}\text { Melting Point } \\
\left(C^{o}\right)\end{array}$ \\
\end{tabular} & $\begin{array}{c}\text { Yield } \\
(\%) \\
\end{array}$ \\
\hline 1 & 4-hydroxybenzoic acid hydrazide & $\mathrm{C}_{7} \mathrm{H}_{8} \mathrm{~N}_{2} \mathrm{O}_{2}$ & 152 & White & $115-117$ & 75 \\
\hline 2 & $\begin{array}{l}\text { 4-(4-amino-5-mercapto-4H } 1,2,4- \\
\text { triazole-3-yl)phenol }\end{array}$ & $\mathrm{C}_{8} \mathrm{H}_{8} \mathrm{~N}_{4} \mathrm{OS}$ & 208 & White & $215-217$ & 73 \\
\hline $3 \mathbf{a}$ & $\begin{array}{l}4-(4-(\quad \text { benzylideneamino }) \\
\text { mercapto-4H-1,2,4-triazol-3- } \\
\text { yl)phenol }\end{array}$ & $\mathrm{C}_{15} \mathrm{H}_{12} \mathrm{~N}_{4} \mathrm{OS}$ & 296.35 & Pale Yellow & $157-180$ & 86 \\
\hline $3 b$ & $\begin{array}{l}\text { 4-(4-(4-hydroxy- } \\
\text { benzylideneamino)-5-mercapto- } \\
\text { 4H-1,2,4-triazol-3-yl)phenol }\end{array}$ & $\mathrm{C}_{15} \mathrm{H}_{12} \mathrm{~N}_{4} \mathrm{O}_{2} \mathrm{~S}$ & 312.35 & White & $150-153$ & 82 \\
\hline $3 c$ & $\begin{array}{l}\text { 4-[4- }\{4 \text {-(dimethylamino) } \\
\text { benzylideneamino)-5-mercapto- } \\
\text { 4H-1,2,4-triazol-3-yl)phenol }\end{array}$ & $\mathrm{C}_{17} \mathrm{H}_{17} \mathrm{~N}_{5} \mathrm{OS}$ & 339.41 & Red & $198-200$ & 67 \\
\hline $3 d$ & $\begin{array}{l}\text { 4-(4-(4-bromobenzylidene- } \\
\text { amino)-5-mercapto-4H-1,2,4- } \\
\text { triazol-3-yl)phenol }\end{array}$ & $\mathrm{C}_{15} \mathrm{H}_{11} \mathrm{BrN}_{4} \mathrm{OS}$ & 375.24 & Pale Yellow & $180-182$ & 86 \\
\hline $3 e$ & $\begin{array}{l}\text { 4-(4-(2-aminobenzylidene- } \\
\text { amino)-5-mercapto-4H-1,2,4- } \\
\text { triazol-3-yl)phenol }\end{array}$ & $\mathrm{C}_{15} \mathrm{H}_{13} \mathrm{~N}_{5} \mathrm{OS}$ & 311.36 & Dark brown & $200-202$ & 63 \\
\hline $3 f$ & $\begin{array}{l}\text { 4-(5-mercapto-4-(4-methyl- } \\
\text { benzylideneamino)-4H-1,2,4- } \\
\text { triazol-3-yl)phenol }\end{array}$ & $\mathrm{C}_{16} \mathrm{H}_{14} \mathrm{~N}_{4} \mathrm{OS}$ & 310.37 & Yellow & $138-140$ & 87 \\
\hline $3 g$ & $\begin{array}{l}\text { 4-(5-mercapto4-(4-nitro- } \\
\text { benzylideneamino)-4H-1,2,4- } \\
\text { triazol-3-yl)phenol }\end{array}$ & $\mathrm{C}_{15} \mathrm{H}_{11} \mathrm{~N}_{5} \mathrm{O}_{3} \mathrm{~S}$ & 341.34 & Yellow & $170-172$ & 61 \\
\hline $3 h$ & $\begin{array}{l}\text { 4-(5-mercapto-4-(4- } \\
\text { methoxybenzylideneamino)-4H- } \\
\text { 1,2,4-triazol-3-yl)phenol }\end{array}$ & $\mathrm{C}_{16} \mathrm{H}_{14} \mathrm{~N}_{4} \mathrm{O}_{2} \mathrm{~S}$ & 326.37 & $\begin{array}{l}\text { Yellowish } \\
\text { Orange }\end{array}$ & $148-150$ & 89 \\
\hline $3 \mathbf{i}$ & $\begin{array}{l}\text { 4-([4-(4-chlorobenzylidene- } \\
\text { amino)-5-mercapto-4H-1,2,4- } \\
\text { triazol-3-yl)phenol }\end{array}$ & $\mathrm{C}_{15} \mathrm{H}_{11} \mathrm{ClN}_{4} \mathrm{OS}$ & 330.79 & Yellow & $188-190$ & 76 \\
\hline $3 \mathbf{j}$ & $\begin{array}{l}\text { 4-((2-(3-hydroxyphenyl) } \\
\text { mercapto-4H-1,2,4-triazol-4- } \\
\text { ylimino)methyl)phenol }\end{array}$ & $\mathrm{C}_{15} \mathrm{H}_{12} \mathrm{~N}_{4} \mathrm{O}_{2} \mathrm{~S}$ & 312.35 & Yellow & $206-208$ & 74 \\
\hline
\end{tabular}

Compound (1) has been synthesized from methyl benzoate and hydrazine hydrate in absolute ethanol and confirmed by the appearance of the stretching vibration bands at (3309, 3280) $\mathrm{cm}^{-1}$ belongs to terminal amino group, and by shifting of the intense stretching vibration band from 1700 to $1624 \mathrm{~cm}^{-1}$ for $(\mathrm{C}=\mathrm{O})$ of amide group. A stretching vibration band is also seen at $3197 \mathrm{~cm}^{-1}$ for NH group.

The formation of compound (2) was confirmed through appearance of two bands at $948 \mathrm{~cm}^{-1}$ and $1265 \mathrm{~cm}^{-1}$ which referring to $\mathrm{N}$ $\mathrm{C}-\mathrm{S}$ and $\mathrm{N}-\mathrm{N}-\mathrm{C}$, respectively. In addition of two other characteristic bands at 3174 and 2573 due to $(\mathrm{N}-\mathrm{H}$ form) and $(\mathrm{S}-\mathrm{H})$ stretching vibration, respectively. This indicates a thiolthion equilibrium. The nucleus 4-(4-amino-5mercapto-4H-1,2,4-triazol-3-yl)phenol (2) was used to synthesize Schiff's bases (3a-3j). FTIR spectra of prepared Schiff bases indicate a disappearance of $(\mathrm{N}-\mathrm{H})$ stretching band of primary amine at (3250-3400) $\mathrm{cm}^{-1}$ and appearance of stretching band at (1597-1634) $\mathrm{cm}^{-1}$ belong to the formation of imino group $(\mathrm{HC}=\mathrm{N})$. FT-IR characteristic spectral for all compounds are listed in the Tab. (2).

The ${ }^{1} \mathrm{H}$ NMR spectrum of compound (2) shows the following chemical shifts $(\delta / \mathrm{ppm})$ at: $5.72\left(s, 2 \mathrm{H}, \mathrm{NH}_{2}\right), 3.39(s, 1 \mathrm{H}, \mathrm{NH}), 6.88-$ $7.86(\mathrm{~m}, 4 \mathrm{H}, \mathrm{H}$-aromatic ring), and $10.73(s$, $1 \mathrm{H}, \mathrm{OH})$. As shown in Fig. (3). The chemical shifts for compound (3c) shows 3.01-3.15 (m, $\left.6 \mathrm{H}, \mathrm{N}\left(\mathrm{CH}_{3}\right)_{2}\right), 6.78-8.13$ ( $m, 4 \mathrm{H}, \mathrm{H}$ aromatic), $8.80(\mathrm{~s}, 1 \mathrm{H}, \mathrm{CH}=\mathrm{N})$ 9.14(s, $1 \mathrm{H}, \mathrm{OH}), 13.92(\mathrm{~s}$, $1 \mathrm{H}, \mathrm{SH})$. 
Table (2)

FT-IR characteristic Spectral bands of compounds 1, 2 and 3a-j.

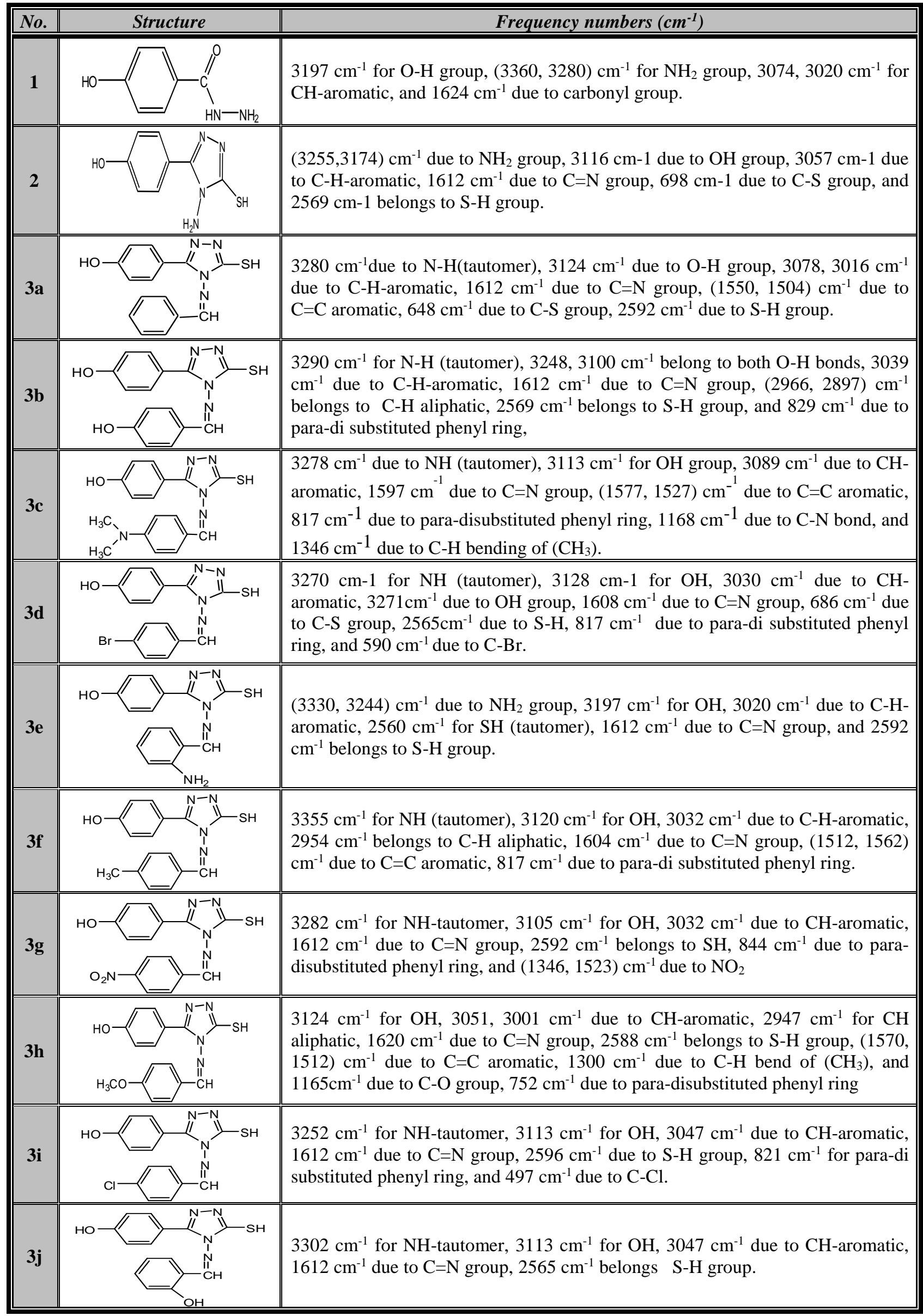




\section{Conclusions}

From FT-IR and ${ }^{1} \mathrm{H}$ NMR spectroscopic data can be concluded that the final compounds were recognized to exist as thiolthione and as keto-enol tautomers because the high degree of conjugation in this system due to presence of the hydroxyl, amine and thiol groups and $\mathrm{sp} 2$ hybridized carbon atoms. The high degree of planarity and high content of heteroatoms like oxygen, nitrogen, and sulfur atoms are required in these compounds to be studied in future work.

\section{Acknowledgments}

Staff and head of Chemistry Department of College of Science of Al-Nahrain University are gratefully acknowledged for kindly providing most required materials and apparatus.

\section{References}

[1] Bulut VN, Duran C, "A Triazole Derivatives as a New Acid-Base Indicator", Bull. Chem. Soc, Ethiop, 24(3), 457-460. 2010.

[2] Abdul Hameed A., Hassan F, "Synthesis, Characterization and Antioxidant Activity of Some 4-Amino-5-phenyl-4H-1,2,4triazole-3-thiol Derivatives", Int. J. App. Sci. Tech., 4(2), 202-211, 2012.

[3] Sancak K, Ünver Y, Unluer D, Dugdu E, Kor G, Celik F \& Birinci E, "Synthesis, characterization, and Antioxidant Activities of New Trisubstituted Triazoles", Turk. J. Chem., 36, 457-466, 2012.

[4] Hanif M, Saleem M, Hussain MT, Rama NH, Zaib S, Aslam MAM, Jones PG. Iqbal J, "Synthesis, Urease Inhibition, Antioxidant and Antibacterial Studies of Some 4-Amino-5-aryl-3H-1,2,4-triazole-3thiones and their 3,6-Disubstituted 1,2,4Triazolo[3,4-b]1,3,4-thiadiazole Derivatives", J. Braz. Chem. Soc, 23 (5), 854-860, 2012.

[5] Bekircan O, Kahveci B, "Synthesis and Anticancer Evaluation of Some New Unsymmetrical 3, 5-Diaryl-4H-1,2,4triazole Derivatives", Turk J Chem., 30, 2940, 2006.

[6] Bekircan O, Menteşe E.Ülker S, "Synthesis of Some New 1,2,4-Triazole Derivatives Starting from 3-(4-Chlorophenyl)-5-(4methoxybenzyl)-4H-1,2,4-triazol with Anti-
Lipase and Anti-Urease Activities" ,Pharm. Chem. Life Sci, 347, 387-397, 2014.

[7] Amin KM. El-Zahar MI, "Synthesis and Anticancer Activity of Novel, Tetralin-6ylpyridine and Tetralin-6-ylpyrimidine Derivatives", Acta. Polo. Pharm. Drug Res., 66(3), 279-291, 2009.

[8] Sripriya S, Subha C. Selvaraj A., "The Inhibition Chemistry of 2-Amino, 5-phenyl 1,3,4-triazole for Aluminium in Hydrochloric Acid Solution", IOSR-JAC., 6(2), 25-29, 2013.

[9] Meenaxi MM. Ainapure, "Triazolone and Their Derivatives for Anti-Tubercular Activities", Asian J. Res. Chem., 4(7), 1050-1054, 2011.

[10] Husain A, Naseer MA. Sarafroz M, "Synthesis and Anticonvulsant Activity of Some Novel Fused Heterocyclic 1,2,4-Triazolo-[3,4-b]-1,3,4-thaidiazole Derivatives", Acta. Polo. Pharm. Drug Res., 66(2), 135-140, 2009.

[11] Alswah M. Ghiaty A, "Synthesis and Biological Evaluation of Some [1,2,4] Triazolo [4,3-a] quinoxaline Derivatives as Novel Anticonvulsant Agents", ISRN Org. Chem., 1,1-7, 2013.

[12] Streeter DG, Witkowski JT. Khare GP, "Mechanism of Action of 1- $\beta$-DRibofuranosyl-1,2,4-triazole-3-carboxamide (Virazole). A New Broad-Spectra Antiviral Agent", Proc. Nat. Acad. Sci. USA., 70(4), 1174-1178, 1973.

[13] Singh RG. Singh DJ, "Novel Synthetic Approach to Some New 1,2,4Triazolothiadiazines and 1,2,4Triazolothiadiazinones and Their AntiInflammatory Activities", Int. J. Chem. Tech. Res., 1(4), 1239-1243, 2009.

[14] Mousa MN. Al-jadaan SAN, "Evaluation of The Anti-Inflammatory Activity and Ulcerogenic Liability of 5-(3-Chloro-1benzothien-2-yl)-4-phenyl-4H-1,2,4triazole-3-thiol”. Bas. J. Vet. Res., 11(1), 122-127, 2012.

[15] Zarrouk, A., Hammouti, B. Al-Deyab, S.S. Salghi, R. Zarrok, H. Jama C. Bentiss, F. "Corrosion Inhibition Performance of 3,5-Diamino-1,2,4-triazole for Protection of Copper in Nitric Acid Solution", Int. J. Electrochem. Sci., 7, 5997-6011, 2012. 
[16] Kim, D. K, Kima, J. Park, H, "Design, synthesis, and biological evaluation of novel 2-pyridinyl-[1,2,4] triazoles as inhibitors of transforming growth factor type I receptor. Bioorg". Med. Chem., 12, 2013-2020, 2004.

[17] Vaibhav S, Dinesh K. M, Suman B Rina $\mathrm{D}$, "A review on biologically active Schiff base derivatives", Int. J. Pharm Bio. Sci., (4), 2319-8141, 2013.

[18] Aljourani J., Raeissi K., \& Golozar M.A, "Benzimidazole and its derivatives as corrosion inhibitors for mild steel in $1 \mathrm{M}$ $\mathrm{HCl}$ solution, Corros". Sci., 51 (8), 18361843, 2009.

[19] Asan A., Kabasakaloglu M., Is Kalan M., Kilic Z, "Corrosion inhibition of brass in presence of terdentate ligands in chloride solution", Corros. Sci, 47 (6), 15341544,2005 .

[20] Jacob K. S., Parameswaran G, "Corrosion inhibition of mild steel in hydrochloric acid solution by Schiff base furoin thiosemicarbazone", Corros. Sci., 52 (1), 224-228, 2010.

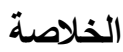

تم تخليق قواعد شف جديدة تحوي في تركيبها حلقة

1,2,4- ترايازول الخماسية (3a-j) من المركب 4,4-امينو -

5- مركابتو -4H -1,2,4- ترايازول -3- ايل (2) والذي

بدوره حضر من تفاعل الحولقة لمركب 4- هيدروكسي

حامض البنزويك هايدرازايد (1). تم تشخيص المركبات

بواسطة طيف الاشعة تحت الحمراء وطيف الرنين النووي

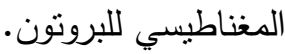

